\title{
SEED PRODUCTION AND SEED QUALITY OF THE DUNE BUILDING GRASS PANICUM RACEMOSUM SPRENG.
}

\author{
Cesar Vieira Cordazzo ${ }^{1.2}$ \\ Anthony John Davy ${ }^{2}$ \\ Recebido em 07.07.93. Aceito em 07.07.94.
}

\begin{abstract}
Seed production and seed quality of the dune-building grass Panicum racemosum Spreng.). Seed production, pollination requirement, seed characteristics related to quality and the relationship between number and mass of seeds were examined for Panicum racemosum in three successional populations in southern Brazilian coastal dunes. The seed production was generally low and declined further between the frontal dunes and the backdunes, dropping from 4.05 seeds per panicle in the former to 1.8 seeds in the latter. However fertility (\% fertile florets) did not differ among the three habitats. Plants cross-pollinated in a glasshouse showed an increase in seed production to 41.4 seeds compared to no seed production in self-pollinated plants. Caryopses varied in mass from 3.2 to $12.2 \mathrm{mg}$ with a mean of $7.98 \mathrm{mg}$. A strong negative correlation was found between mean individual seed mass and the total number of seeds per panicle in a natural population. However, this relationship did not persist in seeds produced by cultivated plants in the glasshouse. The causes of low seed production appear to be mainly pollen self-incompatibility and additionally competition for nutrients between sexual reproduction and allocation to clonal growth. Under conditions of nutrient shortage, Panicum racemosum probably allocates resources more to clonal growth and to fewer, but well-endowed seeds. This would permit emergence from deeper burial sand, faster growth and greater survival of seedlings.
\end{abstract}

RESUMO - (Produção e qualidade da semente da gramínea Panicum racemosum Spreng. em um gradiente de dunas costeiras). A produção de sementes, polinização, características das sementes e a relação entre o número e peso de sementes foram examinadas em três populações de Panicum racemosum ao longo de um gradiente nas dunas costeiras no sul do Brasil. A produção de sementes foi pequena e decresceu ao longo do gradiente, diminuindo de 4,05 sementes por espiga nas dunas frontais para 1,8 sementes por espiga nas dunas mais estáveis. Entretanto não ocorreram diferenças na feitilidade entre as populações. Plantas cultivadas em casas de vegetação e que foram polinizadas cruzadamente mostraram um aumento na produção de sementes (41,4 sementes) em comparação com as plantas auto-polinizadas (nenhuma semente). As sementes variaram em relação à massa de 3,2 a 12,2 mg com uma média de 7,98 mg. Uma forte correlação negativa foi encontrada entre a massa individual das sementes e o número total de sementes por espiga nas sementes coletadas nas dunas frontais. As causas da baixa produção de sementes parecem ser principalmente devido à

\footnotetext{
' Departamento de Oceanografia, Universidade do Rio Grande, Caixa Postal 474, CEP 96500-900, Rio Grande-RS, Brasil.

'School of Biological Sciences, University of East Anglia, Norwich, NR4 7TJ, UK.
} 
incompatibilidade do pólen na auto polinização e, devido à competição por nutrientes entre a reprodução sexuada e crescimento vegetativo. Em condições de deficiencia em nutrientes, provavelmente Panicum racemosum utiliza mais recursos em crescimento vegetativo e baixa produção de sementes, mas de boa qualidade. Isto, poderia permitir que as plântulas originadas destas sementes possam emergir de maiores profundidades na areia, terem maior crescimento e sobrevivência.

Key words: Panicum racemosum, seed production, pollination, seed mass, seed number, coastal dunes.

\section{Introduction}

Panicum racemosum Spreng. is a warm-season, C4, perennial grass with a wide distribution from Argentina $\left(35^{\circ} \mathrm{S}\right)$ to northeastern Brazil $\left(8^{\circ} \mathrm{S}\right)($ Smith et al.,1982; Costa et al.1991). On southern Brazilian foredunes, Panicum racemosum is the dominant dune-building grass on the first dune ridge (Cordazzo \& Seeliger, 1993). It has considerable economic potential because of its dune-building and sand-binding abilities (Pfadenhauer 1980, Costa et al. 1991, Cordazzo \& Seeliger 1993) which are similar to those of Uniola paniculata and Ammophila species. P. racemosum appears to be very well adapted to the conditions prevailing in this environment (Pfadenhauer 1980) and strongly influences the plant community and dune formation (Cordazzo \& Seeliger 1993).

Despite its notable importance in the coastal environment, little is known specifically about the reproductive biology and ecology of Panicum racemosum. Most studies have been concerned with taxonomic and distributional aspects. Only a few studies have considered its growth, leaf demography and decline in vigour along the environmental gradient of a dune succession (Costa et al. 1984, 1991).

Costa et al. $(1984,1991)$ reported that Panicum racemosum can reproduce sexually and spread by clonal growth. However, populations of Panicum racemosum in southern Brazil are maintained principally by clonal growth (Pfadenhauer 1978), similarly to other dune-building species such as Uniola paniculata (Wagner 1964), Ammophila arenaria (Huiskes 1979) and A. breviligulata (Maun \& Baye 1989). Harris \& Davy (1986) found that a very low percentage of tillers of Elytrigia juncea (Elymus farctus) produced inflorescences but, after a catastrophic tidal surge, seeds and rhizome fragments were of similar importance in giving rise to new colonies. According to Laing (1958) only $0.02 \%$ of new shoots in a population of Ammophila breviligulata had originated from seedlings. The survival of plants originating from rhizome fragments is usually high, probably because of stored reserves and the presence of root primordia on rhizome fragments (Maun \& Baye 1989). Thus, dunebuilding plants tend to allocate a small proportion of resources to flowering culms (Maun 1985). In addition, many authors have supposed that the number of seeds is limited by competition among developing ovules for pollen or nutrients, and between fruits and other organs for limiting resources (Lloyd 1980). Another important element in the reproductive strategy of a plant concerns the partitioning of its seed output either 
into many small seeds or a few large ones. Within the constraints of a given reproductive allocation there is clearly antagonism between seed size and number (Fenner 1985, Silvertown \& Lovett Doust 1993).

The objectives of this study were (a) to determine seed production rates and the mechanisms that limit them in Panicum racemosum populations across an environmental gradient in southern Brazil, (b) to examine seed mass and dimensions, and (c) to investigate whether the number of seeds produced is related to seed quality.

\section{Material and methods}

Studies were conducted on Panicum racemosum plants growing in coastal foredunes of the state of Rio Grande do Sul (southern Brazil). For details of locations and site descriptions see Costa et al. (1991) and Seeliger (1992).

Total culm density and flowering culm density were recorded in December 1991 in 100 randomly selected quadrats $(0.5 \times 0.5 \mathrm{~m}$.) in each of the three $P$. racemosum habitats (frontal, top and backdunes). Seed production and floral characteristics were determined by collecting 25 flowering culms from each habitat. Florets were removed manually from each panicle and separated into filled (those containing a caryopsis) and unfilled (those without a caryopsis). The number of seeds (caryopses) per panicle was recorded as well as the number of florets per panicle and the panicle length.

Fecundity and percentage fertility were determined using the methodology described by Krajnyk \& Maun (1982) for Ammophila breviligulata populations. Thus, fecundity was definied as potential reproductive performance, determined by counting the number of florets on a panicle. It was assumed that each floret had the potential to produce a normal well-developed caryopsis. Fertility was calculated as the number of well-developed caryopses per panicle divided by the number of florets.

In January 1991 seedlings of Panicum racemosum (5 days old) were individually planted in $26-\mathrm{cm}$ diameter plastic pots filled with $4: 1$ sand and potting compostmixture (John Innes no.2). All plants were maintained in an unheated glasshouse at the University of East Anglia, Norwich until they produced inflorescences. Nutrient solution (NPK 7:7:7, 1g/l) was supplied every two months. Fifty flowering culms of Panicum racemosum from the glasshouse were separated in two groups early the in flowering season. Twenty-five flowering culms were enclosed in glazed paper bags, so that each panicle was completely isolated from external pollen. In the second group, the panicles were not bagged and were manually cross-pollinated. Mature flowering culms were analysed as described previously.

Mass and length of 450 caryopses selected at random from field collections were recorded using an electronic balance and calipers, respectively. Cumulative means of seed mass were calculated with increasing sample size. When sample size exceeded 300 seeds, mean seed mass and variance remained fairly constant, and it was thus assumed that the 450 -seed sample reflected true variation in the seed population. Mean mass of seeds and number of seeds per panicle were recorded.

Differences in seed production and floral characteristics were tested for statisti- 
cal significance with a one-way analysis of variance (ANOVA). Tukey's multiple range test was used when the ANOVA showed a significant difference (Sokal \& Rohlf 1981).

Five replicates of $500 \mathrm{~g}$ of sand were collected monthly from each habitat at $5 \mathrm{~cm}$ depth between October and December 1991. These samples were used to determine phosphate, nitrate, calcium, potassium and $\mathrm{pH}$. Potassium and calcium were extracted with $1 \mathrm{M}$ ammonium acetate at $\mathrm{pH} 7$ (Allen et al.1976) and determined by atomic absorption spectrometry. Nitrate was extracted from sand with $\mathrm{NaCl}(6 \%)$ solution, and phosphate was extracted with $0.5 \mathrm{M}$ sodium bicarbonate at $\mathrm{pH} 8$ (Allen et al. 1976). Both, phosphate and nitrate were measured using colorimetric methods, similar to the methodology described by Costa et al. (1991) for the same sites. The pH was determined using a Cole Palmer $\mathrm{pH}$ meter, on a 1:1 mixture by volume of sand and distilled water.

\section{Results}

Panicles of Panicum racemosum are spike-like, erect, contracted, more or less interrupted below, continuous and moderately dense above and 10.5 to $27 \mathrm{~cm}$ long (Table 1). The densities of culms and flowering culms (those with panicles) are heterogeneous in each habitat (Table 1). The ranges of density of culms were 20-84, 16-80 and 8-76 per square meter for frontal, top and backdune habitats, respectively (Table 1). Mean number of culms per square meter did not differ significantly between frontal and top dunes, but it was significantly lower in the backdunes (Table 1).

Mean density and range of density of panicles differ significantly along the habitat gradient (Table 1) with an average of $38.1 \pm 1.5,28.3 \pm 1.2$ and $8.2 \pm 0.9$ for frontal, top and backdunes, respectively. The ratio of panicles (flowering culms) to all culms was significantly different for each habitat, with averages of $0.70,0.62$ and 0.25 (Table 1), in frontal, top and backdunes, respectively.

Fecundity (total number of florets per panicle) varied among the different habitats of the dune system, ranging from 140 to 68.3 (Table 1). In all three habitats a large proportion of florets on each panicle (about $91 \%$ ) contained shrivelled caryopses which had either not developed beyond the stage of floral maturation or had developed for a short period after fertilization and then aborted (the pericarp and testa had developed but were empty). A small number of florets $(5.08 \%)$ was entirely empty and only $3.38 \%$ had well-developed caryopses (seeds).

Plants of Panicum racemosum started to produce inflorescences only in the third spring after sowing (2 years old). The results of glasshouse experiments (Table 2) showed that the mean number of seeds produced in cross-pollinated plants was tenfold higher than in the field, with a mean of $41.4 \pm 2.9$ seeds. The ratio of seeds/florets from cross-pollinated plants was 0.3 , fifteenfold higher than in the field. The bagged flowering culms (self-pollinated) did not produce any seed. Length of panicles and number of florets produced were not statistically different among field, glasshouse cross-pollinated and glasshouse self-pollinated plants. 
Table 1. Reproductive variation of Panicum racemosum populations of Southern Brazil. Means \pm SE are based on 100 samples in each area.

\begin{tabular}{lccc}
\hline & FRONTAL & TOP & BACKDUNE \\
\hline Culms per square meter & $47.6 \pm 1.7$ & $46.4 \pm 1.6$ & $32.7 \pm 1.7$ \\
& (a) & (a) & (b) \\
Range of culms density & $20-84$ & $16-80$ & $8-76$ \\
Panicles per square meter & $34.1 \pm 1.5$ & $28.2 \pm 1.1$ & $8.20 \pm 0.8$ \\
& (a) & (b) & (c) \\
Range of panicle density & $8-72$ & $8-60$ & $0-32$ \\
Ratio panicles/culms & $0.69 \pm 0.01$ & $0.61 \pm 0.01$ & $0.24 \pm 0.02$ \\
& (a) & (b) & (c) \\
Length of panicles (cm) & $17.4 \pm 9.9$ & $15.9 \pm 3.4$ & $13.4 \pm 4.1$ \\
Florets per panicle & (a) & (a) & (b) \\
Seeds per panicle & $140 \pm 9.1$ & $83.1 \pm 4.1$ & $68.3 \pm 6.6$ \\
& (a) & (b) & (b) \\
Ratio seeds/florets & $4.05 \pm 0.7$ & $2.00 \pm 0.2$ & $1.80 \pm 0.4$ \\
& (a) & (b) & (b) \\
Seeds per square meter & $0.027 \pm 0.001$ & $0.024 \pm 0.001$ & $0.029 \pm 0.001$ \\
& (a) & (a) & (a) \\
& $138 \pm 1.1$ & $56.5 \pm 0.3$ & $14.7 \pm 0.4$ \\
\hline
\end{tabular}

* Means with the same letter in the row are not statistically different according Tukey's multiple range test.

Panicum racemosum is not a heavy seed producer. Mean number of seeds per panicle declined along the habitat gradient from $4.1 \pm 0.7$ to $2.0 \pm 0.3$ to $1.8 \pm 0.5$ in the frontal, top and backdunes, respectively (Table 1). However, fertility (ratio of number of seeds per panicle to all florets in the panicle) did not differ significantly along the habitat gradient (Table 1). Seed length varied from 4.2 to $5.3 \mathrm{~mm}$. Mean seed length was $4.75 \pm 0.02$ (mean \pm standard error), which was lower than the mode $(5.02 \mathrm{~mm}$ ). Seed mass of Panicum racemosum varied from 3.2 to $12.2 \mathrm{mg}$ per seed. Mean individual seed mass of this whole population was $7.92 \pm 0.08$, which was higher than the mode $(7.8 \mathrm{mg})$. The frequency distribution of seed mass was skewed to the right $(\mathrm{g} 1=-0.3273)$ and platykurtic $(\mathrm{g} 2=-0.3155)$ (Figure 1$)$.

Correlation between seed mass and length did not show a significant relation$\operatorname{ship}(\mathrm{F}=0.5227 ; \mathrm{P}<0.5)$, with a correlation coefficient of 0.073 . Thus, heavier seeds were not necessarily longer.

A multiplicative model regression analysis of mean individual seed mass per panicle on the total number of seeds per panicle (Fig. 2) showed a significant relationship $(\mathrm{F}=10.67 ; \mathrm{P}<0.01)$, with a correlation coefficient of -0.7783 . Thus, panicles of Panicum racemosum that produced a smaller number of seeds allocated 


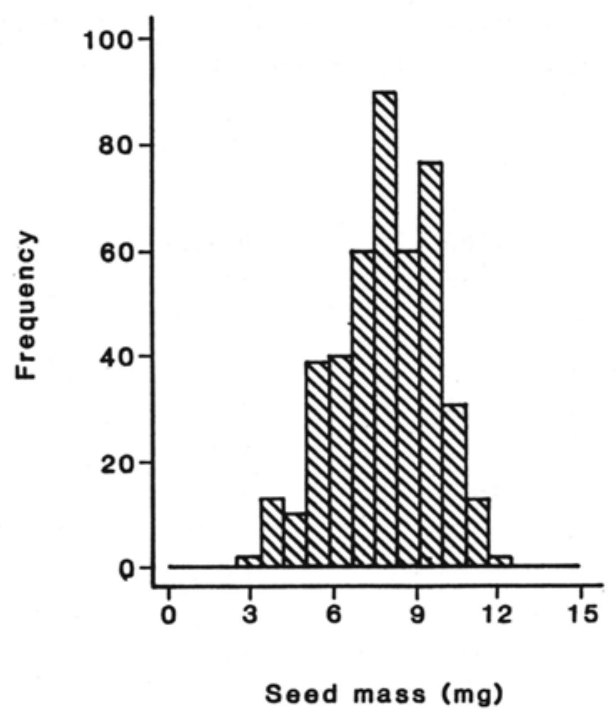

Figure 1. Frequency distribution of seed mass in Panicum racemosum $(n=450)$ from a frontal natural population in coastal sand dunes in southern Brazil.

greater mass per seed. However, the relationship between seed mass and seed number per panicle from cultived plants in glasshouse, was not significant $(\mathrm{F}=0.517 ; \mathrm{P}<0.5)$, with a correlation coeficient of -0.155 .

Table 2. Comparison of reproductive characteristics of Panicum racemosum from frontal natural population in southern Brazil with cross- and self-pollination plants cultivated in a glasshouse. Means \pm SE are based on 100 samples from the natural habitat and 50 samples from glasshouse.

\begin{tabular}{lccc}
\hline & FIELD & \multicolumn{2}{c}{ GLASSHOUSE } \\
\cline { 3 - 4 } & & CROSS- & SELF-POLLINATED \\
\hline Length of panicles $(\mathrm{cm})$ & $17.4 \pm 9.9$ & $19.0 \pm 1.3$ & $19.6 \pm 1.1$ \\
Florets per panicle & (a) & (a) & (a) \\
& $140 \pm 9.1$ & $137 \pm 4.3$ & $146 \pm 5.1$ \\
Seeds per panicle & (a) & (a) & (a) \\
& $4.05 \pm 0.7$ & $41.4 \pm 2.9$ & 0 \\
Ratio seeds / florets & (a) & (b) & - \\
& $0.02 \pm 0.01$ & $0.30 \pm 0.02$ & \\
\hline
\end{tabular}

* Means with the same letter in the row are not statistically different according Tukey's multiple range test. 


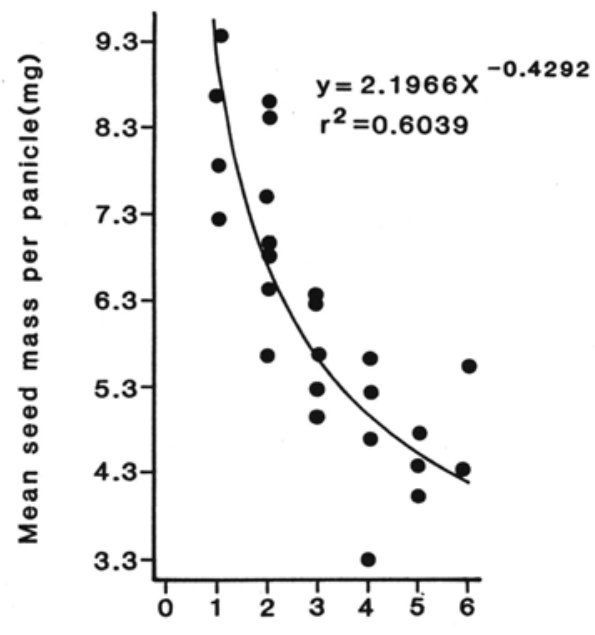

Number of seeds per panicle

Figure 2. Relationship between mean individual seed mass and the number of seeds per panicle, for 25 Panicum racemosum panicles from a southern Brazilian frontal dune population.

Soils of all three habitats had very low concentrations of phosphate, nitrate and potassium, and a clear gradient of decreasing nutrient availability occurred from frontal to backdunes (Table 3).

\section{Discussion}

A marked variation in Panicum racemosum culm density and flowering culm density along the environmental gradient in southern Brazilian coastal foredunes was detected, confirming the observations made in the same area by Costa et al. (1991). However, culm density and flowering culm density recorded in this study were substantially different from those in previous studies. Costa et al. (1991) found culm densities of $75 ; 18.75$ and 15.62 culms per square meter, and 28.82; 6.16 and zero flowering culms per square meter in frontal, top and backdunes, respectively. The inconsistencies with this study are probably because the earlier studies employed only a single permanent quadrat $(2 \times 2 \mathrm{~m})$ in each habitat, and Panicum racemosum has a very heterogenous distribution in each habitat (Cordazzo \& Seeliger 1993). Hence, the previous studies probably over-estimated the density in frontal dunes and underestimated the densities in top and backdunes. There may also be variation between years.

Like other dune-building grasses such as Uniola paniculata (Wagner 1964), Ammophila arenaria (Huiskes 1979) and A. breviligulata (Maun \& Baye 1989), Panicum racemosum allocated a small proportion of its resources to flowering culms, and plant vigour and density were correlated with moderate sand accretion (Pfadenhauer 1980, Costa et al. 1991). Flowering culms showed higher densities in habitats 
with active or recent sand accretion. Following dune stabilization, the density and proportion of flowering culms diminished markedly, probably because of the decline of vigour of the population (Costa et al.1991).

Table 3. Nutrient concentrations (means $\pm \mathrm{SE}$ ) of sands $(5 \mathrm{~cm}$ depth) in three different habitats occupied by Panicum racemosum populations in Southern Brazilian coastal dunes

\begin{tabular}{llll}
\hline & FRONTAL & TOP & BACKDUNE \\
\hline Nitrate $(\mu \mathrm{g} / \mathrm{Kg})$ & $252.4 \pm 36.1$ & $219.5 \pm 38.7$ & $199.0 \pm 45.6$ \\
Phosphate $(\mu \mathrm{g} / \mathrm{Kg})$ & $543.2 \pm 35.4$ & $663.2 \pm 84.3$ & $484.7 \pm 56.2$ \\
Calcium $(\mathrm{mg} / \mathrm{Kg})$ & $342.6 \pm 61.4$ & $429.1 \pm 66.3$ & $472.5 \pm 72.3$ \\
Potassium $(\mathrm{mg} / \mathrm{Kg})$ & $18.2 \pm 1.7$ & $8.7 \pm 1.4$ & $5.3 \pm 1.1$ \\
$\mathrm{pH}$ & $8.2 \pm 0.4$ & $7.7 \pm 0.3$ & $7.4 \pm 0.4$ \\
\hline
\end{tabular}

Only a small proportion of florets on a panicle contains normal well-developed caryopses. The reasons for this are obscure and need further investigation. Krajnyk \& Maun (1982) suggested that the causes of low fertility in Ammophila breviligulata populations could be non-viable pollen, insect damage, sensitivity to environmental factors, shortage of pollen and meiotic abnormalities. Studies on seed production in another dune grass, Uniola paniculata also demonstrated low seed production (Hester \& Mendelssohn, 1987), with an average of $2.55 \pm 0.64$ seeds per culm, which is even lower than that found in the Panicum racemosum population studied. Like most grasses, Panicum racemosum is wind-pollinated and each floret contains a single ovule and so can produce only one seed (caryopsis). One possible explanation for this extremely low seed production is that cross-pollination may be required for Panicum racemosum to produce an appreciable number of seeds; this is not an unusual requirement among perennial grasses (Hubbard 1984, Schemske \& Lande 1985). For cross-pollination, the species would require pollen from parents with a different genetic constitution, which may not be readily available because the population may have low genetic variability as a result of very extensive clonal growth (vegetative reproduction by rhizomes) (Pfadenhauer 1980) and rare establishment of new genetic individuals from caryopses (Cordazzo \& Seeliger 1988a, Costa et al. 1991). This hypothesis was supported by the results obtained in glasshouse experiments; panicles that received pollen from another genetic individual showed a significant increase in seed production over plants in the field, whereas panicles that were bagged did not produce any seed at all. This result also precludes apomixis, which occurs widely in the family Poaceae (Bashaw \& Hanna 1990). A further factor that may affect successful pollination in the field is rainfall, because a moderate shower virtually eliminates pollen grains from the atmosphere, and the flowering period in Panicum racemosum is very short (Cordazzo \& Seeliger 1988b).

A large number of caryopses was wrinkled; pericarp and testa remained empty despite an apparent initial growth. Emptiness of pericarp and testa may be caused by: 
(a) the abortion of less vigorous zygotes due to competition within the genetically diverse zygote populations, similar to that which occurs in Ammophila breviligulata (Krajnyk \& Maun 1982); (b) shrivelling of caryopses, a common occurrence in the family Poaceae, which could result from water deficits at the flowering stage (Shaw \& Laing 1966, Ekanayake et al. 1989), extremes of temperature at anthesis (Clary 1965) or meiotic abnormalities (Laing 1958); (c) selective elimination; by eliminating some seeds, the plant allocates more resources to vegetative growth, which is active in Panicum racemosum during spring-summer (Costa et al. 1984);(d) an in-built strategy which leads to the production of only a small number of relatively large seeds.

The relation between seed mass and number is subject to marked variation in some species (Salisbury 1942, Wulff 1986, Michaels et al. 1988), with a possible trade-off between seed size and seed number (Silvertown 1989). Sometimes there is a negative correlation between seed mass and number, sometimes a positive one (Silvertown 1989), or none at all. A plant that has ample nutrients may invest more in seed resources than a plant experiencing a shortage of nutrients but plants presumably optimize their seed mass according to the amount of resources available to the maternal plant (Harper 1977). Although, coastal sand dunes are exposed to a constant nutrient input from salt spray (van der Valk 1974), the capacity of the sandy soils to retain these nutrients is low, in the face of high leaching activity. The relatively deficient nutrient status of southern Brazilian dunes may restrict seed number and seed size. Thus, under less favourable conditions of nutrient availability, especially during the later phases of reproduction, the competition between the developing seeds for resources may lead to a negative correlation between their number and individual mass (Werner \& Platt 1976, Wulff 1986). However, when nutrients are not limiting, as in the glasshouse experiments, the competition for resources was not detectable.

The abortion of seeds may be of adaptive significance because a fixed quantity of assimilates would be available for fewer ovules thus increasing or maintaining the size of the seed produced (Hawke \& Maun 1989). So, the low percentage seed set and the negative correlation between seed mass and seed number in Panicum racemosum may be of adaptive significance for two reasons. First, low seed set implies greater amounts of assimilates for maturing ovules, resulting in greater mass per seed (Krajnyk \& Maun 1982). Second, larger seeds may represent more advanced embryo development, with a subsequent reduction in the time taken to germinate (Marks \& Truscott 1985), a greater possibility of emergence from greater depth of burial by sand (Maun \& Lapierre 1986), and faster growth and greater survival probability of the seedlings (Zhang \& Maun 1991).

Damage by a beetle of the family Anthicidae also accounts for a small reduction in the number of viable caryopses in the Panicum racemosum populations studied. However, insect infestation of the panicles was not addressed in this study and may require further investigation.

In conclusion, the extremely low seed production in natural populations of Panicum racemosum appears to be due mainly to self-incompatibility; it requires cross-pollination to produce viable seeds. In southern Brazilian coastal dunes, clones 
may be very extensive giving little opportunity for out-breeding. Additionally, under conditions of low nutrient availability, common in coastal sand dunes, the competition between sexual reproduction and allocation to clonal growth may lead to a negative correlation between the seed number and individual mass. Further studies are necessary to investigate the effect of pollination and nutrient supply on seed production in natural environments and examine variations in seed production among different populations of Panicum racemosum throughout its geographic distribution.

\section{Acknowledgements}

We thank Dr. D.C.Wildon and Dr. G.F. Bishop for valuable critiques of the manuscript and CAPES (proc. 1141/90-5) for financial support to this Ph.D. project.

\section{References}

Allen, S.E.; Grimshaw, H.M., Parkinson, J.A., Quarmby, C. \& Roberts, J.D. 1976. Chemical analysis. In: Chapman, S.B. (ed.) Methods in plant ecology: Oxford: Blackwell Scientific Publications, p. 411466.

Bashaw, E.C. \& Hanna, W.W. 1990. Apomictic reproduction. In: Chapman, G.P. (ed.) Reproductive versatility in the grasses. Cambridge: Cambridge University Press.

Clary, W.P. 1965. Temperature effects on reproductive processes of Russian wildrye. Agron. J., 57:4-6.

Cordazzo, C.V. \& Seeliger, U. 1988a. Guia Ilustrado da Vegetação Costeira no Sul do Brasil. Rio Grande: Editora da FURG.

Cordazzo, C.V. \& Seeliger, U. 1988b. Phenological and biogeographical aspects of coastal dune plant communities in southern Brazil. Vegetatio, 75:169-173.

Cordazzo, C.V. \& Seeliger, U. 1993. Zoned habitats of southern Brazilian coastal dunes. J. Coastal Res. 9(2): 317-323.

Costa, C.S.B.; Seeliger, U. \& Cordazzo, C.V. 1984. Aspectos da Ecologia populacional do Panicum racemosum Spreng. nas dunas costeiras do Rio Grande do Sul. In: Lacerda, L.D. et al. (eds.) Restingas: origem, estrutura, processos. Niterói: UFF-RJ. p. 395-411.

Costa, C.S.B.; Seeliger, U. \& Cordazzo, C.V. 1991. Leaf demography and decline of Panicum racemosum populations in coastal foredunes of southern Brazil. Can. J. Bot., 69:1593-1599.

Ekanayake, I.J.; De Datta, S.K. \& Steponkus, P.L. 1989. Spikelet sterility and flowering response of rice to water stress at anthesis. Ann. Bot., 63:257-264.

Fenner, M. 1985. Seed ecology: New York: Chapman \& Hall.

Harper, J.L. 1977. Population biology of plants. London: Academic Press.

Harris, D. \& Davy, A.J. 1986. Regenerative potential of Elymus farctus from rhizome fragments and seed. J. Ecol., 74: 1057-1067.

Hawke, M.A. \& Maun, M.A. 1989. Interpopulation variation in reproduction and seed mass of a beach annual; Cakile edentula var. lacustris. J. Coastal Res., 5(1):103-112.

Hester, M.W. \& Mendelssohn, I.A. 1987 . Seed production and germination response of four Louisiana populations of Uniola paniculata (Gramineae). Amer. J. Bot. 74(7):1093-1101.

Hubbard, C.E. 1984. Grasses. A guide to their structure, identification, uses and distribution in the British Isles. Harmondsworth: Penguin Books Ltd.

Huiskes, A.H.L. 1979. Biological Flora of the British Isles: Ammophila arenaria (L.) Link. J. Ecol., 67:363-382.

Krajnyk, I. \& Maun, M.A. 1982. Reproductive biology of Ammophila breviligulata. Amer. Midl. Nat., 108:346-354. 
Laing, C.C. 1958. Studies in the ecology of Ammophila breviligulata. I. Seedling survival and its relation to population increase and dispersal. Bot. Gaz., 19:208-216.

Lloyd, D.G. 1980. Sexual strategies in plants. I. An hyphothesis of serial adjustment of maternal investment during one reproductive session. New Phytol., 86: 69-79.

Marks, T.C. \& Truscott, A.J. 1985. Variation in seed production and germination of Spartina anglica within a zoned salmarsh. J. Ecol., 73:695-705.

Maun, M.A. 1985. Population biology of Ammophila breviligulata and Calamovilfa longifolia on Lake Huron sand dunes. I. Habitat, growth form, reproduction, and establishment. Can. J. Bot., 63: 113124.

Maun, M.A. \& Lapierre, J. 1986. Effects of burial by sand on seed germination and seedling emergence of four dune species. Amer. J. Bot., 73:450-455.

Maun, A.M. \& Baye, P.R. 1989. The ecology of Ammophila breviligulata Fern. on coastal dune sytems. Reviews in Aquatic Sciences, 1(4):661-681.

Michaels, H.J.; Benner, B., Hartgerink, A.P., Lee, T.D., Rice, S., Willson, M.F. \& Bertin, R.I. 1988. Seed size variation: magnitude, distribution, and ecological correlates. Evol. Ecol., 2: 157-166.

Pfadenhauer, J. 1978. Contribuição ao conhecimento da vegetação e de suas condições de crescimento nas dunas costeiras do Rio grande do Sul. Rev. bras. Biol., 38:321-364.

Pfadenhauer, J. 1980. Die vegetation der kustendünen von Rio Grande do Sul, sul brasiliens. Phytoecoenologia, 8: 321-364.

Salisbury, E.J. 1942. The reproductive capacity of plants. London: Bell and Sons.

Schemske, D.W. \& Lande, R. 1985. The evolution of self-fertilization and inbreeding depression in plants. II. Empirical observations. Evolution 39: 41-52.

Seeliger, U. 1992. Coastal foredunes of southern Brazil: Physiography, Habitats, and Vegetation. In: Seeliger, U. (ed.) Coastal Plant Communities of Latin America. San Diego: Academic Press. p. 367381.

Shaw, R.H. \& Laing, D.R. 1966. Moisture stress and plant response. In: Pierre, P.W.et al. (eds.) Plant environment and efficient water use. Am. Soc. of Agron., p.73-94.

Silvertown, J. 1989. The paradox of seed size an adaptation. Trends in Ecology and Evolution, 4(1):24-26.

Silvertown, J. \& Lovett-Doust, J. 1993. Introduction to plant population biology: Oxford: Blackwell Scientific Publications.

Smith, L.B.; Wasshausen, D.C. \& Klein, R.M. 1982 Gramineae. In: Flora Ilustrada de Santa Catarina. Itajai: Herbario Barbosa Rodrigues.

Sokal, R.R \& Rohlf, F.J. 1981. Biometry. W.H. New York: Freeman and Company.

Van der Valk, A.G. 1974. Mineral cycling in coastal foredune plant communities in Cape Hatteras National Seashore. Ecology; 55:1349-1358.

Wagner, R.H. 1964. The ecology of Uniola paniculata L. in the dune strand habitat of North Carolina. Ecol. Monogr., 34(1):79-96.

Werner, P.A. \& Platt, W.J. 1976. Ecological relationships of co-occurring goldenrods (Solidago: Compositae). Amer. Nat., 110: 959-971.

Wulff, R.D. 1986. Seed size variation in Desmodium paniculatum I. Factors affecting seed size. J. Ecol., 74: 87-97.

Zhang, J. Maun, M.A. 1991. Establishment and growth of Panicum virgatum L. seedlings on Lake Erie sand dune., Bull. Tor. Bot. Club., 118(2):141-153. 